\title{
Krzysztof Wielecki
}

Pontifical Academy of Social Science, Roma

University of Cardinal Stefan Wyszyński, Warsaw, Poland

(D) https://orcid.org/0000-0002-6532-8491

\section{Subjectivity vs. Agency: The Meaning of Karol Wojtyla’s The Acting Person 1}

\begin{abstract}
Karol Wojtyła's Osoba i czyn (in English translation known as The Acting Person) is certainly an extraordinary book having considerable significance for contemporary human philosophy. And because the philosophical or quasi-philosophical concept of the human person, consciously or not, explicitly or implicitly, is always at the root of any sociological, psychological, pedagogical or even economic theory, the importance of this work is even greater. It involves both the humanities and social sciences. The purpose of this article is to point out the benefits of this groundbreaking book. In particular, it allows us to rethink the paradigmatic foundations of these sciences. At the same time, it attempts to show how necessary is a critical revision of their own paradigmatic basis.

I would also like to consider the essence of the human concept, especially from the perspective of critical realism. Especially, I deal with the issue of subjectivity and justification for the choice of this concept as the key to understanding individual agency. I am convinced that agency is only one dimension of subjectivity and does not allow us to understand the whole problem of autonomy, human freedom, and the meaning of humanity. Wojtyła's The Acting Person seems to provide extremely important arguments in favor of my thesis. It also helps, I think, to understand the essence of individual subjectivity, issues of fundamental importance in our time, peculiarly, in the broadly understood human sciences.
\end{abstract}

Keywords: Karol Wojtyła, person, act, subjectivity, agency

${ }^{1}$ Karol Wojtyła, Osoba i czyn (Kraków: Polskie Towarzystwo Teologiczne, 1969); Karol Wojtyła, The Acting Person, trans. Andrzej Potocki, https://www.scribd.com/doc/57487848/TheActing-Person, accessed October 28, 2020. 
Let us start with Karol Wojtyła's remarks on the significance of the phenomenalist experience of oneself and the world as a valuable clue in the study of the essence of the human person and humanity in general. We read: "Man's experience of anything outside of himself is always associated with the experience of himself, and he never experiences anything external without having at the same time the experience of Himself." ${ }^{2}$ Therefore, it can be said that we get to know ourselves by exploring the world, but also the world reveals the man in experiencing of what is what, in a sense, the world? - is transcendent to us, which illustrates an argument for phenomenological cognition. At least when it comes to the subject's self-knowledge.

However, Wojtyła noticed a certain weakness in building knowledge about the human person on the analysis of the cognitive act. He wrote:

The phenomenalistic standpoint seems to overlook the essential unity of the distinctive experiences and to attribute the unitary nature of experience to its allegedly being composed of a set of sensations or emotions, which are subsequently ordered by the mind. Undoubtedly, every experience is a single event, and its every occurrence is unique and unrepeatable, but even so there is something that, because of a whole sequence of empirical moments, may be called the "experience of man." The object of experience is the man emerging from all the moments and, at the same time, present in every one of them (we disregard here all other objects) $\left[\ldots . .^{3}\right.$

The above quotation indicates that the later Holy Father overtook the position of critical realism, which indicates the reality of being, including the subject. It cannot be reduced to occasional impressions, but the mentioned experience indicates the subject as something (someone) relatively stable, autonomous, emergent - as it could be said - identical with each other, discovering at different times. This allegation, of course, refers to phenomenology to a lesser extent, especially its realistic variant.

However, in these cognitive acts, as Wojtyła suggests, not only the subject but also the human person in general emerges. We read: "But men other than myself are also the objects of my experience."4 In fact, it also means something more. Although each experience is separate and unique-as has just been mentioned - in this diversity and variability the human experience emerges in general, as such. We read: "The experience of oneself, however, is still the experience of man; it does not extend beyond the limits of an experience that includes all humans, that is, man himself." ${ }^{5}$ Thus, we experience ourselves as

\footnotetext{
2 Wojtyła, The Acting Person, 5.

${ }^{3}$ Ibid.

${ }^{4}$ Ibid., 6.

5 Ibid., 7.
} 
a separate, unique phenomenon, but we also experience ourselves as a human being, part of the human species. Although I experience myself "from the inside" ("inner experience"), and other people as "external experience," then "other human beings in relation to myself are but the 'outerness,' which means they are in opposition to my 'innerness'; in the totality of cognition these aspects complement and compensate each other, while experience itself in both its inner and outer forms tends to strengthen and not to weaken this complementary and compensating effect." 8

In The Acting Person, phenomenalism and phenomenology are carefully separated. This distinction is of particular importance when the Author moves on to the ontology and epistemology of the eponymous act. He wrote: "Thus, in every human experience, there is also a certain measure of understanding of what is experienced. This standpoint seems contrary to phenomenalism, but fits very well with phenomenology." "Here is how Wojtyła describes the act in a phenomenological way, namely, "action serves as a particular moment of apprehending - that is, of experiencing - the person. [...] The datum 'man-acts,' with its full experiential content, now opens itself for exfoliation as a person's action." 10

From the perspective of critical realism, one could probably say that the act connects the subject with reality. It is also an act of creation of both the subject and the world of that subject. The process of creation by deed can lead the subject to the ontic state of a person - to use the language of Wojtyła (and personalists, in general). Actually, an act requires and creates a person. The later pope wrote: "Action is not a single event but a processlike sequence of acting; and this corresponds to different agents. The kind of acting that is an action, however, can be assigned to no other agent than a person. In other words, an action presupposes a person," person." ${ }^{\prime 2}$ In Wojtyła's ontology, deed is a basic category. But it also has both fundamental epistemic significance (it is about the act of getting to know oneself and the world by man) and epistemological, that is, "it lies in the nature of the correlation inherent in experience, in the very nature of man's acting, that action constitutes the specific moment whereby the person is revealed. Action gives us the best insight into the inherent essence of the person and allows us to understand the person most fully. We experience man as a person, and we are

\footnotetext{
6 Ibid.

7 Ibid.

8 Ibid., 8.

9 Ibid., 10.

10 Ibid.

11 Ibid.

12 Ibid.
} 
convinced of it because he performs actions." ${ }^{\text {13 }}$ As a sidenote, it is also worth noting the subtle dialectic of ontology and epistemology in this work. This is another reason to claim that the Author was a precursor of critical realism in the version of Roy Bhaskar and Margaret S. Archer. ${ }^{14}$

What is more, the act reveals not only the ontic and epistemic dimension of humanity, but also the moral one. If we accept that the paradigm defines theory or scientific orientation in three dimensions: ontological, epistemological, and ethical, it becomes clear that Wojtyła proposed a new and extremely important paradigm of the philosophy of the human person, which creates a new paradigmatic perspective for sociology, psychology, anthropology, and economics, and in fact, for most of the humanities. We read: "Our experience and also our intellectual apprehension of the person in and through his actions are derived in particular from the fact that actions have a moral value: they are morally good or morally bad." 15

Time may try to present the essence of Wojtyła's view of what an act is. He wrote:

"Action," in the sense it is used here, is equivalent to the acting of man as a person. While "human act" shows such action as a specific manner of becoming based on the potentiality of the personal subject, the terms act or action themselves tell us nothing about it. They seem to denote the same dynamic reality but, in a way, only as a phenomenon or manifestation rather than as an ontic structure. It does not mean, however, that they prevent us from gaining access to this structure. On the contrary, both action and conscious acting tell us of the dynamism proper to man as a person. It is owing to this intrinsic content that they comprise all that is meant by "human act" $[. .]^{16}$

Here we come to the extremely important question of the ontical nature of man, which - as Wojtyla understood it-leads us directly to the essence of subjectivity. He wrote:

By "action" is meant acting consciously. When we say "conscious acting" we implicitly refer to the kind of acting that is related to and characteristic of the will. Thus the phrase to some extent corresponds to the actus voluntarius of Scholastic philosophy, since any acting pertaining to the human will must also be conscious. We can now see even more vividly how condensed is the meaning of "action" or of the corresponding "conscious acting" of everyday speech. In it are contained the ontological meanings, which belong to the human act,

${ }^{13}$ Ibid.

${ }^{14} \mathrm{Nb}$., Margaret S. Archer was invited by John Paul II into Pontifical Academy of Social Sciences.

15 Ibid., 10.

${ }^{16}$ Ibid., 20. 
as well as the psychological meanings, which are traceable in such attributives as the Latin voluntarius or the English conscious. ${ }^{17}$

This reasoning led the author to "the total, overall conception of the manperson." 18 So the subject becomes an act of our own consciousness-therein lies a key transformation of "what" into "who." Nonetheless, this does not happen beyond act. As we read: "Man owes to consciousness the subjectivation of the objective. Subjectivation is to some extent identifiable with experiencing; at least, it is in experience that we become aware of it."'19

The attribute of consciousness makes the subject reflective and reflexive. Let us explain the extremely important differences between these two concepts. The then cardinal, bishop of Cracow, wrote:

Reflexivity of consciousness means its natural turn towards the subject as such. Reflexivity is something other than reflectivity, inherent in the human mind and its acts. Reflexivity presupposes the intentionality of acts of thinking, i.e. their return to the object. Thinking becomes reflective when we turn to an act previously accomplished, to grasp its objective content more fully, or its character or structure. Reflective thinking is an important element in the creation of all understanding, all knowledge, including self-knowledge, which is self-knowledge. It directly serves consciousness and its development in man, [...] however, awareness does not constitute thinking. The mental turn towards the subject as such is constitutive for her-consciousness is reflexive, not reflective. ${ }^{20}$

The subtlety with which Wojtyla understands the subject appears in the following passage:

In reflection, the subject is still included as an object. The reflexive turn means that this object, which ontologically is the subject, experiences itself not as the subject-which means he experiences his own "I." It is something new and something different from all previous categories: it is something else to be the subject, something else - to be known (objectified) as the subject, also in the reflection of consciousness - and the subject's subjective experience is something else. Man is the subject of his existence and action, he is the subject as a being of a specific nature, which has its consequences in action. This

17 Ibid., 21.

${ }^{18}$ Ibid., 30. I prefer to translate this as "an integral concept of man as a person"-K.W.

19 Ibid., 31. My suggestion on how to translate this passage is the following: "It is thanks to consciousness that what is object becomes subjective. The person himself becomes the subject, as well as activities in mutual relations, everything that constitutes the intentional 'world of persons' also becomes subjective"-K.W.

${ }^{20}$ Wojtyła, Osoba i czyn, 46; translation mine-K.W. 
entity of existence and action, which is man, ontology defines the expression of a suppositum. ${ }^{21}$

Here we come across another motif of the similarity of Wojtyła's theory to critical realism, and, in particular, the concept of the human person, which Margaret S. Archer developed in Being Human ${ }^{22}$ and then in Structure, Agency and the Internal Conversation ${ }^{23}$ or in The Reflexive Imperative in Late Modernity, ${ }^{24}$ where she wrote that we live today in a time of "reflective imperative," a multitude of new previously unknown situations in which only on the path of reflectiveness can one reconcile one's own concerns with the social context. In this process, the identity and personality of the human person are constituted. Archer also pointed to the importance of this process, which she calls emotional commentary. Wojtyła wrote:

While emotions themselves occur or happen in man, he is aware of them, and owing to this awareness he can in a way control them. The control of emotions by consciousness has a tremendous significance for the inner integration of man. Obviously, the sway consciousness exerts over emotion is not achieved outside the sphere of the will and without its cooperation. Hence it is only against the background of such control that we can form moral values. We are thus faced with the fact of interpenetration of consciousness and the will; the control of consciousness over the spontaneous emotive dynamism conditioning the exercise of the free will — the proper function of the will - is simultaneously conditioned by the will. ${ }^{25}$

Literature in the field of human sciences distinguishes two basic orientations of fundamental theoretical importance. Some of them treat man as a product of society, culture, and nature. Others emphasize human independence, creativity, ambitions, and abilities to influence the world and co-create it. The latter are referred to as subjective. On their fundamental basis, agency seems to be the issue, that is, the effective fulfillment of the will of the subject. One of the more popular orientations of this kind in sociology is interactionism, with its clearly constructivist foundation. We ask here not so much about how the world creates man, but how man creates the world. The answer is that this happens in interactions. In these relationships among themselves, people construct society,

${ }^{21}$ Ibid., 46-47; translation mine-K.W.

${ }^{22}$ Margaret S. Archer, Being Human: The Problem of Agency (Cambridge: Cambridge University Press, 2000).

${ }^{23}$ Margaret S. Archer, Structure, Agency and the Internal Conversation (Cambridge: Cambridge University Press, 2003).

${ }^{24}$ Margaret S. Archer, The Reflexive Imperative in Late Modernity (Cambridge: Cambridge University Press, 2012), 68.

${ }^{25}$ Wojtyła, The Acting Person, 38. 
culture and themselves, guided by rational choice or negotiating among themselves. The third way among social theories is Margaret S. Archer's concept of central conflation, which rejects such one-sided assumptions and even attempts to reconcile them mechanically (e.g., Anthony Giddens and Pierre Bourdieu). She believes that in reality we are dealing with separate, real and emergent entities: culture, society, and human beings, which enter into complicated and mutual relationships. As a result, structures are formed, but also the identity of reflective entities develops. ${ }^{26}$

As for me, I am in favor of a subjective position, but I raise two fundamental reservations about it. The first concerns the narrowing of the concept of subjectivity to subjective action. I believe that this is only one important dimension. The second doubt concerns the effectiveness of action as a defining feature of subjectivity. I claim that for an action to be subjective, its effectiveness is not necessary. Especially if you understood it as the ability to meet your own needs, wants or interests in isolation from subjective values. I wrote a lot about the danger of the so-called instrumental reason, here I will not develop this thread. It is important for our reasoning that I firmly separate the concept and phenomenon of subjectivity (subjectivity, and in Wojtyła's translation into English by Father Andrzej Potocki-subjectiveness) vs. agency (and in translation-efficacy). I find support in Karol Wojtyła's The Acting Person who wrote that

we reach the conclusion that within the integral experience of man, especially with reference to its inner aspect, we can trace a differentiation and even something like a contrast of subjectiveness and efficacy. Man has the experience of himself as the subject when something is happening in him; when, on the other hand, he is acting, he has the experience of himself as the "actor." To such experiences corresponds a fully experiential reality. Subjectiveness is seen as structurally related to what happens in man, and efficacy as structurally related to his acting. ${ }^{27}$

We have clearly marked the difference in the meanings of a fundamental nature. I have mentioned the issue of moral values, which determine when we decide whether a given act is subjective. However, at the same time, as Wojtyła wrote, action necessarily introduces us to ethics:

It is by means of the moral value which man crystallizes through actions as enhancing his own being that these actions, or man's conscious acting, are

${ }^{26}$ I refer here to the author's works mentioned earlier, I write more about it in: Krzysztof Wielecki, "Sociology at a Crossroads: The Significance of Margaret S. Archer's Theory," in Cricital Realism and Humanity in the Social Sciences, ed. Klaudia Śledzińska and Krzysztof Wielecki [Archerian Studies, vol. 1] (Warszawa: Wydawnictwo Uniwersytetu Kardynała Stefana Wyszyńskiego, 2016), 27-45.

${ }^{27}$ Ibid., 51. 
brought down to the exercise of the moment of freedom. This freedom is best visualized by the human being in the experience aptly epitomized in the phrase, "I may but I need not." It is not so much a matter of the content of consciousness alone as of a manifestation and actualization of the dynamism proper to a man. This dynamism is in the line of acting, and it is along this line that it becomes part of the efficacy of the personal ego but remains distinct from all that only happens in man. The manifestation and actualization of the dynamism proper to man must have its correlate in the potentiality of the man-subject. We call the correlate the will. Between the "I may" on the one hand and, on the other, the "I need not," the human "I want" is formed, and it constitutes the dynamism proper to the will. The will is what in man allows him to want. ${ }^{28}$

We now get a more complete picture of the concept of man outlined in The Acting Person. Indeed, the ontic nature of man arises and reveals himself as a free being and entangled in value. As we read:

When we search deep into the integral structure of moral conduct and becoming, into the integral structure of man's becoming morally good or morally bad, we find in it the proper moment of freedom. It is in the structure of man's becoming, through his actions, morally good or bad, that freedom manifests itself - most appropriately. Here, however, freedom is not only a moment; it also forms a real and inherent component of the structure, indeed, a component that is decisive for the entire structure of moral becoming: freedom constitutes the root factor of man's becoming good or bad by his actions; it is the root factor of the becoming as such of human morality. It also takes place in efficacy and thus plays a decisive role in man's acting. By being interwoven with efficacy, freedom and efficacy together determine not only acting or action itself, which are performed by the personal ego, but their moral goodness or badness, that is to say, the becoming of man morally good or bad as man. ${ }^{29}$

Thus, the entanglement of an act in values means a moment of freedom, that is, freedom of choice of an ethical nature. It is a definitional feature of the human being: "The discovery of freedom at the root of the efficacy of the person allows us to reach an even more fundamental understanding of man as the dynamic subject." ${ }^{30}$ But freedom is not necessarily related to the effectiveness of actings for what one wants. An act transcends man, and it also opens him or her to transcendence. Because beyond the deed, in the very essence of human,

\footnotetext{
28 Ibid., 70.

29 Ibid.

30 Ibid.
} 
what happens only in man has no dynamic source; it lacks the element of freedom and the experience of "I may but I need not." In the perspective of the person and of his proper dynamism, that is, as dynamized by action, everything that happens in man is seen to be dynamized out of inner necessity without the participation of the moral becoming of man free from constraints, in this dynamism; the moment of the dynamic transcendence is lacking; however, the moment of freedom is immanent to the conditions of man's moral becoming and connected with the causation by nature. Action proper, on the other hand, exhibits - owing to the causation by the person - the transcending feature that passes into the immanence of the acting process itself: for acting also consists in the dynamization of the subject. ${ }^{31}$

Thus, freedom is a subjective property, but only when we understand it as the freedom of making an act dependent on subjective values - sometimes it also involves independence from what someone wants:

A complete description of the will cannot refer simply to the moment of "willing" alone, neither to the exercise nor to the experience of "I will," in which is contained the moment of freedom identifiable with the experience of "I may but I need not." Although these experiences are an essential element of the action - as well as of morality - the will and the inner freedom of man have still another experiential dimension. In it the will manifests itself as an essential of the person, whose ability to perform actions derives directly from the possession of this essential rather than from some inherent feature of the action performed by the person. ${ }^{32}$

Now it is only at this moment of our reasoning that we come to the point where Wojtyła's other concept of self-determination becomes necessary. He wrote: "Every action confirms and at the same time makes more concrete the relation, in which the will manifests itself as a feature of the person and the person manifests himself as a reality with regard to his dynamism that is properly constituted by the will. It is this relation that we call 'self-determination."'33

A satisfactory summary of the theory of Wojtyła's human person cannot be presented in a short text. This is not my goal anyway. Rather, I tried to point to Wojtyła's strong arguments in opposing the notion of subjectivity and agency. To close the threads that I have touched upon here, I will present one more quote from the work of Wojtyła. He wrote:

Any adequate image of the person's integration in the action has to include the principle of complementarity; integration complements the transcendence

\footnotetext{
31 Ibid., 70-71.

32 Ibid., 72.

33 Ibid.
} 
of the person, which is realized through self-determination and efficacy. In this dimension human action is a conscious response through choice or decision to a value. But also this response has always to make use in one way or another of somatic and psychical dynamisms. The integration of the person in the action indicates a very concrete and, each time, a unique and unrepeatable introduction of somatic reactivity and psychical emotivity into the unity of the action-into the unity with the transcendence of the person expressed by efficacious self-determination that is simultaneously a conscious response to values. But the inclusion of the conscious response to values in the human action takes place in a specific way, that is, through the integration of the whole psychoemotivity of man which is, moreover, indicative of a specific sensibility to values. ${ }^{34}$

In sociology, at one time the so-called equation of Piotr Sztompka's subjectivity was well known. He has presented the following formula: "be the subject = want to act + be able to act." Perhaps this is the equation of agency, but not subjectivity. This, as we already know from the work The Acting Person is more complicated. It contains the aforementioned factor- "I don't have to." In this first proposal, man is free in the sense of being able to do what he wants. He may, however, be free from his inclinations. Therefore, instead of Sztompka's equation, one could propose a Wojtyła's equation: To be the subject = I want + I can + I don't have to. Here, however, the question arises, namely, why should I not do something if I want and can? It seems that Wojtyła would refer to this doubt in the following manner: because sometimes I should not. This "I can" can mean: I can, which means that there are not enough obstacles to my agency. But sometimes I cannot because my values do not let me. So I could but I cannot because of the freedom to choose moral values. As I understand it, yet another aspect of subjectivity emerges from Wojtyła's considerations. I mean a situation where: I don't want to do something + I might not do something, but I should do it. The duty results from moral values which I accepted as a free being. If I can only reduce it to the absence of external obstacles to take action, then internal obstacles for the subject remain. They can have the character of values and desires. But they may also require instrumental skills, by which I mean the characteristics of the subject, such as intelligence, the ability to think abstractly, or immunity from illnesses, no allergies, etc. The type of action and possible external obstacles require specific properties.

To my mind, subjectivity has at least three basic dimensions: subjective values, subjective properties and-finally_-subjective action, that is, agency.

\footnotetext{
${ }^{34}$ Ibid., 152.
} 


\section{Bibliography}

Archer, Margaret S. Being Human: The Problem of Agency. Cambridge: Cambridge University Press, 2000.

Archer, Margaret S. The Reflexive Imperative in Late Modernity. Cambridge: Cambridge University Press, 2012.

Archer, Margaret S. Structure, Agency and the Internal Conversation. Cambridge: Cambridge University Press, 2003.

Wielecki, Krzysztof. "Sociology at a Crossroads: The Significance of Margaret S. Archer's Theory." In Cricital Realism and Humanity in the Social Sciences [Archerian Studies, vol. 1], edited by Klaudia Śledzińska and Krzysztof Wielecki, 27-45. Warszawa: Wydawnictwo Uniwersytetu Kardynała Stefana Wyszyńskiego, 2016.

Wojtyła, Karol. The Acting Person. Translated by Andrzej Potocki. https:/www.scribd.com/ doc/57487848/The-Acting-Person. Accessed October 28, 2020.

Wojtyła, Karol. Osoba i czyn. Kraków: Polskie Towarzystwo Teologiczne, 1969.

Krzysztof Wielecki

\section{Soggettivismo e efficacia - L'importanza della Persona e atto di Karol Wojtyła}

\section{Sommario}

Il libro « Persona e atto » di Karol Wojtyła è certamente un libro straordinario di grande importanza per la contemporanea filosofia dell'uomo. Poiché la concezione filosofica o quasi filosofica dell'uomo, consapevolmente o meno, esplicitamente o implicitamente, è sempre all'origine di ogni teoria sociologica, psicologica, pedagogica e anche economica, questo lavoro è ancora più importante. La sua pertinenza si estende anche sulle discipline umanistiche, comprese le scienze sociali. Lo scopo del presente testo è mostrare i vantaggi dello studio di questo libro rivoluzionario, a mio parere, in queste scienze e in particolare, di ripensare i suoi fondamenti paradigmatici. Allo stesso tempo, si vuole mostrare quanto sia necessario rivedere criticamente le proprie basi paradigmatiche.

Vorrei anche considerare qui l'essenza della concezione dell'uomo, specialmente dal punto di vista del realismo critico. In particolare, mi occupo qui della questione della soggettività e della giustificazione della scelta di questo concetto inteso come chiave per capire l'efficacia individuale e quella collettiva. Sono convinto che l'efficacia sia solo una delle dimensioni della soggettività e non ci permetta di comprendere l'intero problema dell'autonomia, della libertà umana e dell'importanza dell'umanità. «Persona e atto» di Wojtyła sembra fornire argomenti estremamente pertinenti per la mia tesi. Aiuta anche, credo, a comprendere l'essenza della soggettività individuale e collettiva, questione fondamentale nei nostri tempi. In particolare, nelle scienze ampiamente focalizzate sull'uomo.

Parole chiave: Karol Wojtyła, persona, atto, soggettività, efficacia 
Krzysztof Wielecki

$$
\begin{gathered}
\text { Subjectivisme et efficacité - } \\
\text { L'importance de Personne et acte de Karol Wojtyła }
\end{gathered}
$$

Résumé

«Personne et acte» de Karol Wojtyła est certainement un livre extraordinaire d'une grande importance pour la philosophie contemporaine de l'homme. Puisque la conception philosophique ou quasi-philosophique de l'homme, que ce soit consciemment ou non, explicitement ou implicitement, est toujours à la base de toute théorie sociologique, psychologique, pédagogique et même économique, ce travail est encore plus important. Il recouvre également les sciences humaines, y compris les sciences sociales. Le but de ce texte est de montrer les avantages de l'étude de ce livre révolutionnaire, à mon avis, dans ces sciences et de repenser leurs fondements paradigmatiques. En même temps, cela permet de revoir à quel point il est nécessaire de réviser de manière critique ses propres fondements paradigmatiques.

Je voudrais également considérer l'essence de la conception de l'homme, en particulier du point de vue du réalisme critique. Surtout, je traite ici de la question de la subjectivité et de la justification du choix de ce concept comme clé pour comprendre l'efficacité individuelle et celle collective. Je suis convaincu que l'efficacité n'est qu'une des dimensions de la subjectivité et ne permet pas de comprendre tout le problème de l'autonomie, de la liberté de l'homme et de l'importance de l'humanité. «Personne et acte» de Wojtyła semble fournir des arguments extrêmement pertinents pour ma thèse. Cela aide aussi, je crois, à comprendre l'essence de la subjectivité individuelle et collective, une question fondamentale à notre époque. Particulièrement, dans les sciences focalisées sur l'homme.

Mots-clés: Karol Wojtyła, personne, acte, subjectivité, efficacité 